\title{
The Importance of Morocco in the Spanish Civil War
}

\author{
Jarod E. Ramirez \\ University of California, Santa Barbara
}

\section{Introduction}

The Spanish Civil War was essentially the prelude to World War Two and has been subject to many analyses about the course of events and its impact. These analyses mostly focus on aspects of the battles, the social changes that occurred in places such as Catalonia, and the ways various world powers were involved. Most of the talk about the Spanish Civil War is Eurocentric, which makes sense because it occurred in Spain and European powers were involved in the fighting. However, what is often forgotten is that Spain was at the time a colonial power with holdings in Northern Morocco and Equatorial Guinea. There is little discussion on the impact that these colonies had on the war nor on how colonized people were involved. This is despite the fact that the main revolt that started the war did not occur in Spain but in a Moroccan Colony and that Francisco Franco, the main general on the Nationalist side and future dictator of Spain, began his career fighting in Morocco.

Morocco's significance to the Spanish Civil War has been hidden largely due to a lack of historical context of the war along with the racism that permeated from it. When the war is discussed, it can sometimes be mistaken as a conflict that only involved Spanish soldiers. In reality, the combatants were people from all across the world, including but not limited to Cuba, Russia, America, and most relevant to this article, Morocco. The Spanish Republic is framed as a progressive democracy and as Socialist by historians, yet what is forgotten is that the Spanish Republic retained colonies in Africa until 1936. While the Nationalist forces were far more antidemocratic and authoritarian, the exclusion of the Republic's colonial aspirations creates an incomplete history that obscures vital aspects of the war. What is found by studying Morocco is the very foundations of the Civil War, both in terms of the people who fought and its origins.

Spanish and Moroccan history have been connected since the very foundation of the modern Spanish state. The Umayyad caliphate invaded Iberia in 711 and introduced a direct connection between North Africa and the Peninsula. For the next seven hundred years, the Muslim kingdoms of Spain would be the center of a multi-religious and cultural fusion that 
marks Spain to this day. However, by the 14th Century, the northern Catholic Kingdoms of Aragon and Nevarre would begin the Reconquista, the reconquering of Spain in the name of Catholicism. By 1469, the peninsula was unified into two Christian monarchies comprising Portugal and Spain. ${ }^{1}$

The early seeds of beliefs that would later comprise both Colonialism and Fascism were planted in this event. The end of the war brought with it a purge of any non-Catholic religious beliefs in the peninsula. The Catholic Monarchy and Church established the Inquisition whose goal was to convert or kill any Muslim, Jewish, or secular elements still remaining on the continent. Religion was believed by the Spanish church as transferable by blood and this belief developed into the racialization of non-Catholic people as non-white which helped to develop a white Spanish hierarchy. ${ }^{2}$ This idea would influence Spanish society for some time and would later be imported to the Americas in the form of the Racial Casta system. This is not surprising, considering that the Reconquista was still ongoing in 1492 when colonization of the Americas began. However, the Spanish belief of racial superiority would largely be fueled by their perception of "The Moor." Mauraphobia and Mauraphillia were spawned from the conquest and would seek to other the Moor by combining Christian imagery with the killing of non-believers. The image of "The Moor" was depicted through Moros y Cristianos, local events that celebrate the conquest and Catholicization of Spain while denigrating the Moors. Another Maurophobic image is that of Saint James Matamoros the Moor Killer. ${ }^{3}$ Both of these symbols would serve as a way to other their enemies by depicting them as the non-white and non-Christian other wherever Spain colonized.

Spanish Fascism would be born largely in the colonization of Morocco. Fascism has been argued as Colonialism brought home ${ }^{4}$ and the creation of the Nationalist movement in Spain lends support to this claim. The means and tactics by which the Civil War was fought can be traced to Morocco and despite being a Spanish War, the Nationalist forces were made up of large numbers of Moroccan recruits. This alone can attest to the importance of understanding Morocco, but its vital role goes beyond this as the foundations of the war and its outcome were decided by whichever power had Morocco on its side. Morocco's forces and strategic value created the most advantageous position for Franco and the Nationalist forces which prolonged the war to its eventual conclusion. Had Morocco not been a supply zone of well-trained troops, the Nationalist forces on the Peninsula would have been evenly matched with Republican forces.

Morocco, with its interconnected history, created the foundation for Fascism and the inclusion of Moroccans in Nationalist forces contributed to the end of Republican Spain. Furthermore, the complete failure of Republican Spain to ferment an independence revolt in Morocco was not only an example of the colonialist views of the Leftists forces in Spain, but a vital reason for the Republic's ultimate defeat.

\footnotetext{
${ }^{1}$ Lisa Jackson-Schebetta, Traveler, There is no Road: Theater, the Spanish Civil War, and the Decolonial Imagination in the Americas, (Iowa: University of Iowa Press, 2017), 123.

${ }^{2}$ Jackson-Schebetta, Traveler, There is no Road, 124.

3 Ibid, 124.

${ }^{4}$ Aime Ceasire, Discourses on Colonialism, (New York: Monthly Review Press, 2001), 36-37.
} 


\section{Colonialism as Fascism's Birthplace}

Spain began to colonize Morocco in 1909. This point in time is significant as the Spanish Empire had lost its Latin American colonies. In the mind of the Spanish Monarchy and government, Morocco was a way to regain national prominence. The occupation of Morocco and the Rif Wars of the 1920's would be the fundamental place for the birth of Spanish Fascism. The attitude of Spain towards Morocco was the same as the views of any other European colonizer, framing Moroccans as backwards people that had to be civilized by Europeans. What is notable about the Spanish colonization of Morocco is that the forces used to suppress the Moroccans would come to be the same forces that would spread Fascism throughout Spain.

For example, the officers and generals who served in the colonialist ventures were dubbed Africanistas. These officers were more politically conservative compared to the armies on the peninsula and most of the generals favored or actively supported the monarchy in some way. One motivating factor for this would be that King Alfonso XIII was the main supporter and fancier of the colonization wars. ${ }^{5}$ This conservatism was also combined with their glorification of colonialism, as many Africanistas also looked back on the war with fond memories. They saw themselves as crusaders coming to civilize the land with a "parental like" attitude towards the Moroccans. ${ }^{6}$ This paternalism is notable because it developed into the most brutal and authoritarian rule over the Moroccans. The generals developed the use of death squads in their tactics that would be used to suppress the Republican forces in the Civil War. Another development of the Rif Wars was the creation of one of the most important armies of the Spanish Civil War: the Army of Africa. This army was created in order to repress all the attempts by the Rif and Berber Tribes from uniting and fighting off the Spanish. It comprised two different sections, most notably the Regulares section that was made up of Moroccan recruits. ${ }^{7}$ They were used as a suppressive force to put down any resistance in the Moroccan colony. However, the training they received in Morocco would be later used in the Civil War, such as with the use of colonial death squads.

Another important thing to note is that the creation of these two military groups would set the foundations for many of the future Nationalist officers. A large number of the Africanistas would later go on to be the generals and soldiers behind the Nationalist uprising. The most notable of these was Francisco Franco who began his career serving in the Rif War and became the youngest officer to be promoted to general. His development was heavily connected to the Rif Wars as he states "without Africa I can scarcely explain myself to myself, nor can I explain myself properly to my comrades in arms." 8 He and many other Africanistas' colonialist obsession with Morocco was so great that, in 1924 they plotted a coup against the Spanish dictator Primo

\footnotetext{
${ }^{5}$ Hugh Thomas, The Spanish Civil War, (New York: Modern Library, 2001), 89-90.

${ }^{6}$ Thomas, The Spanish Civil War, 89-90.

7 Minda Jerde, “'Brother' North: Morocco's Involvement in the Spanish Civil War,” The Volunteer, January 4, 2013, https://albavolunteer.org/2013/01/\%e2\%80\%9cbrother\%e2\%80\%9d-north-morocco\%e2\%80\%99sinvolvement-in-t he-spanish-civil-war/.

${ }^{8}$ Jackson-Schebetta, Traveler, There is no Road, 129.
} 
de Rivera when he made motions indicating he wished to pull the army out. ${ }^{9}$ Indeed, to many of these generals, Morocco was a second home, and increasingly so after the establishment of the Second Spanish Republic in 1931. The Spanish Republic had introduced numerous reforms that upset the army and the colonial officers. They had been upset by the cut in funding to the army, the changes in the military command, and, most importantly, the introduction of liberal reforms that occurred.

Not only were most of these officers conservative but they were also devout Catholics. This is important because the Second Republic had greatly angered the church by introducing liberal policies such as divorce and the removal of any special church powers in the $1930 \mathrm{~s}^{10}$ Many high-ranking Catholic officials of Spain directly declared the Republic illegitimate ${ }^{11}$ and attempted to mobilize tensions and fears that the Republic was devolving into Communism and Atheism. Priests leading congregations, the Catholic newspaper, and connected organizations were also generating the fear and hatred that would make a Fascist coup "feasible."12 If the progressive reforms of society did not horrify conservative generals into adopting Fascist ideals on their own, the Catholic church would actively pressure them into further supporting them. Many would begin to see Spain as another Morocco, a place that had to be civilized from "Rebellious tribes." 13 The Africanistas would look at Spain with the same paternalism intent on bringing "civilization" to the godless. The Nationalists actively described their revolt as a crusade or something akin to a modern Reconquista. ${ }^{14}$ Francisco Franco even described the revolt as a "Limpieza", or cleaning up of, everything foreign in Spain. In this case, that meant Socialism, Democracy, and anything non-Catholic. ${ }^{15}$

The Spanish form of Fascism was directly created and developed by the colonial wars of Morocco. The ideas and beliefs of many of the nationalist generals first formed with the colonization of Morocco. Even if the Africanista generals were not specifically Fascist, they would have been monarchists or devout Catholics and would have joined their respective factions, such as the Carlists or the Spanish Confederation of Autonomous Rights (CEDA), that would join the Nationalist side of the war. The generals that were fascist would also go on to join the Falange Espanola de las JONS, the largest Fascist organization of the Nationalists. The JONS part is the name of the organization: Juntas de Ofensive Nacional Sindicalista whose founding document expressed the goal of creating a new Spanish Empire that would encompass French Morocco as well as French Algeria. ${ }^{16}$ Fascist aspirations in Spain were either born in the Colonial war or revolved around colonialism in some way. Many of the generals would describe the reasons for starting the uprising using the exact same rhetoric of a colonialist war except this

\footnotetext{
${ }^{9}$ Thomas, The Spanish Civil War, 133.

${ }^{10}$ Sabrina Ramet, Alternatives to Democracy in Twentieth Century Europe: Collectivist Visions of Alternative Modernity, (Baltimore: Central European University Press, 2019), 288.

${ }^{11}$ Ramet, Alternatives to Democracy in Twentieth Century Europe, 288.

12 Ibid 289.

${ }^{13}$ Thomas, The Spanish Civil War, 91.

${ }^{14}$ Ibid 403.

${ }^{15}$ Ibid 909.

${ }^{16}$ Ibid, 107.
} 
time directed at the people in Spain. It is not simply that the Generals of the Nationalists served in Morocco. It is that their experiences and views in Morocco served as an incubation for the later Fascist revolt which demonstrates the important foundational role that Morocco had in the Spanish Civil War.

\section{The Importance of Moroccans during the Civil War}

Not only was Morocco key in the foundations for the Civil War, but it was also key to the Nationalist victory. While the Republican forces of the war were generally ill equipped compared to the Nationalists, at the start, they were generally matched when it came to the army size and in some cases the Republican forces were much larger than the Nationalist forces. However, the first revolt of the war was in Morocco, and in securing the colony for the Nationalist side, the Fascists not only secured a base for the invasion of the peninsula, but they also secured the welltrained Army of Africa that would prove to be decisive in the outcome of the war.

A significant number of Moroccans would make up the Nationalist side; over 80,000 troops alone were part of the Army of Africa. ${ }^{17}$ The Moroccan soldiers recruited into this army served as shock troops for most battles in the Civil War and were an efficient fighting force. These troops had a number of reasons for supporting the Nationalist side ranging from ideological to economic. Many Moroccans joined because, although Franco was ardently Catholic, he made attempts to accommodate the Islamic beliefs of his troops. He professed the idea of "Hispanic Moroccan Brotherhood" and helped to organize religious practices as well as trips to Mecca for Moroccan religious leaders. ${ }^{18}$ There is also the fact that the Spanish Left was viewed as radically atheist by some religious Moroccans who felt that Franco and the Nationalists were the only ones fighting off the anti-religious tide of Spain. However, the two main reasons for Moroccan support were for anti-colonial and economic reasons. The Nationalists had promised not just autonomy to Moroccan leaders but independence for their service. ${ }^{19}$ This swayed a good amount of support and recruitment to the Nationalist side and will be touched upon in more detail when discussing the failure of the Spanish Republic. Another huge factor was simple economic reasons as joining the Nationalist army and the pre-war army paid better. Many flocked to the war or were paid as mercenaries because the current conditions of Morocco were extremely poor. ${ }^{20}$ The conditions of the Spanish colony were underdeveloped and dependent on Spain creating mass poverty for a majority of Moroccan families. These

\footnotetext{
${ }^{17}$ Nazanine Moshiri, "Arabs on both sides of the Spanish civil war," The New Arab, September 1, 2016, https://english.alaraby.co.uk/english/indepth/2016/9/1/arabs-on-both-sides-of-the-spanish-civil-war.

${ }^{18}$ Samir Bennis, "Participation of Moroccans in the Spanish Civil War (Part III)," Morocco World News, March 3, 2013, https://www.moroccoworldnews.com/2013/03/80909/participation-of-moroccans-i n-the-spanish-civil -warpart-iii-2/.

${ }^{19}$ Jackson-Schebetta, Traveler, There is no Road, 145; Samir Bennis, "Participation of Moroccans in the Spanish Civil War (Part II)," Morocco World News, February 4, 2013, https://www.moroccoworldnews.com/2013/02/76826/participation-of-moroccans-in-the-spanish-civil-war-par t-ii/. ${ }^{20}$ Samir Bennis, "Franco's Recruitment of Moroccans in Spanish Civil War: The Forgotten Injustice (Part I)," Morocco World News, July 9, 2012, https://www.moroccoworldnews.com/2012/07/47357/francos-recruitm ent-ofmoroccans-in-spanish-civil-war-the-forgotten-injustice-part-i-2/.
} 
conditions were compounded by recent crop failure in the 1920s which created more poverty and made Northern Morocco even more reliant on Spain. This pushed Moroccans to join the Army of Africa to find a decent income. When the Fascist revolt began, these Moroccans then found themselves serving the Nationalist side.

This heavy recruitment of Moroccans before the war had a decisive effect on the outcome of the conflict. The Moroccan troops greatly tipped the balance of the war in the favor of the Nationalists providing them with more numerous and experienced troops. As mentioned before, Moroccans were used as shock troops when attacking the enemies and, aside from the physical damage they caused, they were also used for psychological terror. The Nationalists used the very existence of Moroccan troops as propaganda, conjuring up images of "The Moor" to insight terror and fear in the Republican populace. ${ }^{21}$ This tactic was very effective and actually did insight fear and outright desertion of Republican forces before battles. More importantly however, Moroccans were present in almost every major battle in the war and served as extra expendable troops for the Nationalists. Moroccan troops were given the deadliest assignments and suffered the most casualties in the army because they were sent in before the rest of the Nationalist forces. ${ }^{22}$ This tactic meant that while the Moroccans of the Army of Africa suffered great losses, the Spanish and European forces could easily secure territory with minimal damage. This let the Nationalists sacrifice as many lives as they wished to drain the Republican forces to defeat.

Their importance was also seen by Nationalist leaders and they saw the Army of Africa as their key to victory. The Fascist generals placed little faith in the troops on the peninsula and focused heavily on securing the support of the Army of Africa before the revolt. ${ }^{23}$ The reason for this is that, unlike the Africanistas, the Peninsulares in the mainland were more liberal in their politics if not explicitly Socialist. ${ }^{24}$ Franco was the conservative General that seemed able to convince the Army of Africa to revolt. It was for this reason that he was given so much prominence by the Nationalist forces. ${ }^{25}$ This importance was also not lost on him as he saw the Army of Africa as a way to help him secure power. ${ }^{26}$ From the perspective of most generals, securing Morocco and the Army of Africa for their coup was the only hope for it being successful. Morocco served as a stable base of operations and supplied a large surplus of troops for the Nationalists. They were well trained and effective on the battlefield and the number of soldiers could break the balance on the peninsula. Without Moroccans, the Republican side would not have necessarily won the war, but it would have put the Nationalists at a disadvantage and made it more difficult for them to defeat the Republican forces by 1939. This also shows why the Nationalist revolt began in Morocco instead of on the peninsula. It wasn't just that the

\footnotetext{
${ }^{21}$ Jerde, “'Brother' North: Morocco's Involvement in the Spanish Civil War."

22 Jackson-Schebetta, Traveler, There is no Road, 146.

${ }^{23}$ Arthur Landis, Spain, The Unfinished Revolution, (New York: International Publishers, 1975), 89.

${ }^{24}$ Landis, Spain, The Unfinished Revolution, 171.

25 Ibid, 90.

26 Ibid.
} 
Nationalists had a secure base in Morocco, but that it was vitally important to their successful war.

\section{Failure of Republican and Revolutionary Policy}

The people of Morocco, however, were not just important for understanding the Nationalist victory. They were also important when understanding the Republican failure. Many historians and observers of the war have noted how decisive an anti-Franco revolt would be for the Republican side. They separately agree that if the Moroccans had revolted against the Nationalists in Morocco, the Fascist forces would have been significantly weakened so as to give the Republicans victory. This anti-Franco revolt never materialized however, and while the Republican forces were being torn apart by infighting, the Nationalists never experienced a large scale anti-nationalist movement in their territory. This is largely due to the Colonial policy and views of the ostensibly Left "Revolutionary" government that discouraged any kind of anticolonial movement to form in Morocco. The actions of the Republican forces and their clinging to colonialism made them lose all support from the Moroccan people which only helped to further their destruction.

One of the first people to discuss the importance of a revolution in Morocco and the main inspiration for this research was George Orwell. During the Spanish Civil War, he served in the Trotskyist POUM militia stationed in Barcelona. He published an account of his experiences titled Homage to Catalonia. Morocco is never mentioned in any great detail in the book, typically being relegated to the description of the Nationalist forces he was fighting while serving. This makes it all the more striking when he describes the failure of the Civil War and the Republican Government. He lists a number of faults of the government and the failure of the Spanish Revolution and then questions why the Republicans never attempted to foment a revolution in Morocco. He states that by fomenting an uprising in Franco's rearguard, the Nationalists would not have been able to maintain the front on the peninsula. Orwell says that all the Popular Front had to do was to "declare Morocco liberated" for this to happen. Instead, Spain had attempted to placate British and French Colonialism. ${ }^{27}$ This small section from his experiences in the war places great emphasis on the importance of the Moroccan people. He also wrote about inciting a revolt in Morocco in 1937, a point at which the war was still not decided. He also spoke about a revolt in Morocco as something that could easily end the war, showing that he recognized its vital role in the conflict as he was serving. As argued in previous paragraphs, the Moroccan troops were decisive for the Nationalists giving them a secure supply of troops. If there was a revolt in Morocco it would not only threaten the base of Fascism, ideologically it might lead Moroccan troops to desertion, mutiny, and to switch sides. It is important to note that he doesn't blame the Moroccans for not rising up against Franco but instead blames the policy of the Popular Front Government. He directly criticized the Spanish Government for placating European colonialism rather than pursuing a revolutionary policy. This

${ }^{27}$ George Orwell, Homage to Catalonia, (Scotts Valley: CreateSpace, 2014), 53. 
highlights the real failure of the Republican government, that being the failure to adhere to any of its revolutionary principles.

An Italian Anarchist involved in the Civil War, named Camillo Berneri also advocated for a revolt in Morocco. Berneri went to Catalonia at the beginning of the revolution and was one of the organizers for the Italian Volunteer column fighting on the Aragon Front. He argued that because Franco's army relied heavily on a "Moorish Contingent", granting independence to Morocco would stir up Rebellion and demoralize the Nationalist forces. ${ }^{28} \mathrm{He}$ also hoped that Moroccans could be won to the side of the revolution and precipitate a revolution in North Africa that would not only hurt Western Capitalism but also the Fascist government in Spain. ${ }^{29}$ For Berneri the Spanish Revolution could win only on "revolutionary" terms, not on purely military basis. A revolution in Morocco would ideologically disrupt the Nationalist forces in such a way that mere battles could not. In this way, he also agrees with Orwell in the assertion that by maintaining its colonial domination, the Republic greatly hurt its war effort.

The Republican government's attitude towards Morocco has a complicated and confusing history that developed long before the Second Republic itself. During the 1920s, Spanish Leftists were anti-colonial and condemned the invasion of Morocco. Anarchists in the CNT-FAI, the largest Anarcho-Syndicalist labor union, staged numerous anti-war demonstrations and antirecruitment revolts in Catalonia that attempted to hurt the war effort in Morocco. ${ }^{30}$ However a change in attitude began to emerge in 1934 during the Austrias Revolution. The Austrias Revolution was an Anarchist and Communist led revolution that sought to establish Communism in Spain and destroy the Second Republic. It was destroyed within a matter of weeks and was put down by the Army of Africa under the command of Francisco Franco. ${ }^{31}$ Most of the army was made up of Moroccans and a lot of the coverage in Republican newspapers was centered on the image of a band of savage moors raping and massacring civilians. ${ }^{32}$ To the Spanish Working class, Austrias would be a symbol of the "brutality" of Moroccan troops, in part developing a racist belief amongst some of the Popular Front. As the Republican forces attempted to develop propaganda against the largely Moroccan Nationalist forces, they developed racist depictions of their enemy.

Although this attitude was not largely widespread as many on the Left were still very anti-colonial, the onset of the war worsened this view. For both sides, the enemy was orientalized as non-Spanish invading "Moors", but the Republicans were different because they revived Reconquista symbols. ${ }^{33}$ Republican forces resurrected the image of Saint James Matamoros during the start of the war and also re-introduced the rallying cry "Moors a La Costa." 34 The

\footnotetext{
${ }^{28}$ Noam Chomsky, On Anarchism, (New York: The New Press, 2013), 85.

${ }^{29}$ Chomsky, On Anarchism, 85.

30 Thomas, The Spanish Civil War, 38.

31 Jackson-Schebetta, Traveler, There is no Road, 129; Elisabeth Allard, "The Crescent and the Dagger: Representations of the Moorish Other during the Spanish Civil War," Bulletin of Spanish Studies 93, no. 6, 970, https://doi.org/10.1080/14753820.2015.1082811.

32 Allard, "The Crescent and the Dagger," 967-968.

33 Ibid 984.

${ }^{34}$ Jackson-Schebetta, Traveler, There is no Road, 130.
} 
rallying call was first used during the Reconquista and harkened back to the idea that the Moors needed to be casted off entirely from the coast of Spain. The propaganda on the Republican side also highlighted heavily the idea that their enemies were "Savage" by depicting the Army of Africa as a band of "moors" that were massacring and raping Spanish Women. ${ }^{35}$ Depictions and propaganda such as this were so troubling and racist that many African Americans who served in the International Brigades were appalled and uncomfortable with the Republican government. ${ }^{36}$ This impart explains the colonialist attitude that the Republican government had towards Morocco. A part of the Popular Front and soldiers did not see Moroccans as anything more than the "Savage Moor", a counter revolutionary enemy that had to be suppressed for serving Fascism. Yet even this is not the full picture of the failure that was the Republic's colonial policy. What truly doomed the Republic entirely was the clinging to European colonialism that had created these views.

A revolt against Franco was not entirely unthinkable in Morocco and was actually more likely regardless of the Republics policies. The Moroccans were not bound to Fascism and did not need to be told to revolt by the Republicans as many people demonstrated their agency as soon as the Civil War started. When the revolt first began, various cities in the north such as Melilla revolted against the Nationalist uprising and managed to form militias that fended off the Fascists for a few days. ${ }^{37}$ During the entire war, various Communist and independence groups sabotaged the Fascists war efforts and helped to foment an anti-recruitment movement in Morocco. Most of the people and many tribes in the Rif also hated Franco and supported the Republic, convincing people not to serve in the war and holding anti-Franco demonstrations. ${ }^{38}$ His unpopularity was so strong that Franco himself feared a revolt would be imminent. He was forced to stop recruiting from the Rif and most of Spanish Morocco and he began to recruit mercenaries from the French colonies towards the end of the war. ${ }^{39}$ As mentioned before, the reason that most Moroccans were held into service was for financial stability and the promise that Morocco would either be given independence or more autonomy. This last reason, the promise of independence was the exact same reason why there was never a full-scale revolt in Morocco on the side of the Republic. The Spanish Republic never made any gestures towards independence or greater autonomy for Morocco which greatly hurt Moroccan support. Despite this, a number of Moroccans trying to gain independence directly approached the Republicans for negotiation.

The first negotiation happened quite early on in the war. A Moroccan nationalist group called the Moroccan Action Committee contacted French Communists in French Morocco and got in touch with the Popular Front groups in Barcelona. David Rousset, a French Communist, was one of the people present throughout the negotiations and saw it as his mission to convince both the Moroccan Nationalists and Republicans to support a revolt in Morocco. He stated that "I

\footnotetext{
${ }^{35}$ Jackson-Schebetta, Traveler, There is no Road, 146-147.

${ }^{36}$ Ibid, 149.

${ }^{37}$ Landis, Spain, The Unfinished Revolution, 102-103.

38 Bennis, "Franco's Recruitment of Moroccans."; Landis, Spain, The Unfinished Revolution, 104.

${ }^{39}$ Landis, Spain, The Unfinished Revolution, 189.
} 
realized that if there was a military uprising in the Spanish Rif, Franco would be caught in a cleft stick and that, moreover, a very difficult situation would be created in the ranks of Franco's Moroccan troops." ${ }^{40}$ He saw that Morocco was strategically important to the war effort in Spain that it could both divert troops from the Spanish front lines as well as cause disruption amongst the troops. Rousset helped to organize a meeting between Moroccan nationalists and members of the CNT-FAI, a prominent leader in the Autonomous Catalan government.

Through negotiations with the Moroccan nationalists, the CNT-FAI and the POUM in Catalonia discussed terms of independence. In the negotiations, the Moroccan leaders expressed that they were ready to lead a military uprising against Franco in exchange for the recognition of independence from the Spanish Republican Government. ${ }^{41}$ As Rousset points out however, the treaty that was finally agreed upon by both the Moroccans and the CNT-FAI and POUM would still maintain ties to the Spanish Government, limiting some of Morocco's autonomy. ${ }^{42} \mathrm{He}$ described it as recognizing independence while still remaining close links to the metropolis and the former colony. Despite this, it was supported by all groups including the Moroccan representatives. It would later be fully supported by the Catalonia Generalitat, the government representing the Catalonia autonomous region.

However, when the treaty of independence reached the larger Spanish Government in Madrid, the negotiations broke down entirely. According to Rousset, the Moroccan committee was met by Largo Caballero, the Prime Minister at the time, who promptly told them that the government could not sign the treaty. Rousset also mentions that there was considerable pressure on the Spanish Government from France and London who outright hated the treaty. ${ }^{43}$ This is further corroborated in Spain: The Unfinished Revolution by Arthur Landis, who writes that Largo Caballero, along with other government ministers, stated that they would vote down any such proposal for fear of losing French and British support. ${ }^{44}$ This ended any real Moroccan support for the Spanish. The prospect of a rebellion in Morocco was very possible and indeed could have happened regardless of Republican intervention. Yet the negligence of the Republican government doomed most of the hope for such a course in the war.

\section{Spanish Eurocentrism and Colonialism}

The Republican's failure to ally with Moroccans was due to their failure to let go of Eurocentrism. Even the Communists and Socialists of the government, groups of people who expressed internationalism and anti-imperialism, still clung to racist and chauvinistic attitudes when it came to the war. As mentioned before, Orwell declared that the government placated French colonialism and Rousset asserted the exact same thing. However, there are also more

\footnotetext{
${ }^{40}$ Miguel Romero, "David Rousset's Testimony," The Spanish Civil War in Euzkadi and Catalonia, Contrasts and Convergences, Notebooks for Research and Study, No. 13. (1991): 41.

${ }^{41}$ Romero, "David Rousset's Testimony," 42.

42 Ibid.

43 Ibid, 43.

${ }^{44}$ Landis, Spain, The Unfinished Revolution, 190-191.
} 
direct assertions from the French Prime minister at the time, Leon Blum himself. Blum was a Socialist Prime Minister, elected on a largely Socialist Popular Front government in 1937. Despite this he feared that any sort of independence or autonomy in Morocco would threaten French power in the region and in Africa. He pressured the Spanish Government against any such negotiations, threatening to stop the already small amount of support France and Britain were giving the Spanish Republic. ${ }^{45}$ He later cited this as his greatest political failure. ${ }^{46}$ Despite the British and French, Spain still could have negotiated with Morocco either way and incited a revolt. What stopped this from happening was the Republic's obsession with French and English support in the war. A large reason that the Caballero government placated France was because they saw France as the only way to win the war through either intervention or military aid. This belief was a great detriment to the Republicans' cause. France and England were the main proponents behind a non-intervention policy in Spain stopping any war support or military intervention on either side of the war. ${ }^{47}$

England itself was very against any support early on, threatening to break all military ties with France if France attempted to help the Socialists in Spain. ${ }^{48}$ This ruined the Republican war effort severely as it allowed the Fascist side to be aided by Italian and German support while the Republicans were left with nothing. In some cases, England also concretely supported the Nationalist side in the war. The Spanish Navy had largely remained loyal to the Spanish Republic, but because of British interference from Gibraltar, the Spanish Navy was unable to blockade the introduction of Moroccan Troops to the peninsula. ${ }^{49}$ In other instances according to "German sources" at the time, England was supplying munitions to France from Gibraltar on the onset of the war. ${ }^{50}$ From this, English support for the Spanish democracy was not just unreliable it was virtually impossible. The only explanation behind England's hidden support for Fascism was that it feared the spread of radical Communism in Europe. The Spanish Left had begun to implement radical social change throughout the country such as collectivizing factories and farms as well as expropriating wealth from Capitalists. This frightened England and its conservative Tory government at the time, pushing it to pull all support for the Republic.

This becomes clearer with the strange involvement of the USSR. The Soviet Union had given aid to Spain, yet the war support received was extremely small in comparison to the war support given by Italy and Germany. ${ }^{51}$ Stalin also wrote directly to Largo Caballero advising him not to hurt or collectivize any "French Bourgeoisie" property or wealth in the country. ${ }^{52}$ This coupled with the Communist Party of Spain's suppression of more radical elements in the government showed that the USSR was more worried about how the conflict in Spain would be perceived rather than who would win it. Indeed, Stalin was more worried about the formation of

\footnotetext{
${ }^{45}$ Landis, Spain, The Unfinished Revolution, 190-191.

${ }^{46}$ Ibid.

${ }^{47}$ Ramet, Alternatives to Democracy, 282-283.

${ }^{48}$ Landis, Spain, The Unfinished Revolution, 197.

${ }^{49}$ Chomsky, On Anarchism, 93-94.

${ }^{50}$ Ibid, 96.

${ }^{51}$ Ramet, Alternatives to Democracy, 284.

${ }^{52}$ Leon Trotsky, The Spanish Revolution (1931-1939), (New York: Pathfinders Press, 1973), 43.
} 
Fascist and Liberal alliances in Europe than he was about who would win in Spain. He feared that a more Communist victory in Spain would frighten France and England in an alliance against the Soviet Union. ${ }^{53}$ Stalin also feared that if the Spanish government fell too quickly, Fascism would be strongly entrenched in Europe. This is the reason why the Soviet Union gave aid to the Republic and signaled that it would be its fervent supporter in stopping Fascism despite not giving substantial aid to the Republic. As such, not only was the Spanish Republic against the Nationalists aided by Italy and Germany, but even its own supporters in Europe, England, France, and the Soviet Union had different political aspirations in Spain and maneuvered in such a way that led to the destruction of the Spanish Republic.

Despite this lack of support and political maneuvering, the Republic still remained loyal to England, France, and the Soviet Union. They saw the European powers as the only nations that could save them from Franco and the Nationalists. Although the Republic was a government made up of radical Socialists, Communists, and Anarchists who professed their internationalism and anti-colonialism, it was still largely Eurocentric in its views and hopes for revolution. This is shown in the colonial manner in which Caballero later approached Moroccans. Largo Caballero was a man described as the "Spanish Lenin", yet he only saw the Moroccans and their independence as a secondary matter in the Spanish Revolution. After the first meeting by the Moroccan Action Committee, Caballero approached Moroccan nationalists again in the hopes of sparking a revolt. However, he did this without promising any autonomy or independence.

Instead, he merely offered money and treated the Moroccans of the Rif as mercenaries that could be bought and used for war. ${ }^{54}$ In other instances, Caballero reportedly tried to sell off part of Spanish Morocco to win concessions from the French and English. ${ }^{55}$ Moroccans of the Rif were largely anti-Franco but the Republic was too tied up into European interests that they could not see that their real allies were not the French or English but the people of Morocco who wanted to free themselves from the same Fascism they fought in Spain.

\section{Conclusion}

In a 1938 article in New Leader, George Padamore, a famous Pan-Africanist Socialist theorist, discussed the use of Moroccan troops in the Spanish Civil War. He highlighted the failure of the Republican government and their policy of continuing Imperialism, noting that most Moroccans did not particularly agree with Fascism but did so out of economic necessity. ${ }^{56}$ He argued that if the Republic had done more to help the Moroccans, the Moroccans would not be fighting for Franco. Padamore also made another argument using the Spanish Civil War as a lesson to French and British workers. He begins by highlighting the fact that in order to obtain the colony in Morocco, The Spanish government first suppressed its own people by installing a

\footnotetext{
53 Thomas, The Spanish Civil War, 326.

54 Ibid, 562.

${ }^{55}$ Chomsky, On Anarchism, 86.

56 George Padmore, "Why Moors help Franco," New Leader, May 20, 1938.
} 
dictatorship and suppressing democracy ${ }^{57}$ In order to suppress the tribes of the Rif, the Spanish workers first had to be suppressed and that this was the price the Spanish people had to "pay for empire." Essentially, the Spanish Civil War was the reverse; in order to suppress the people of Spain, Franco and the Nationalists had to suppress the people of Morocco. Instead of uniting against the same foe, which was Colonialism, the Spanish instead stuck to Europe. As a result, not only were they suppressed, but Moroccans would not have independence for another two decades. He ends his argument by telling workers to beware and that the lesson from the Spanish Civil War is to show "more solidarity in deeds not in words."

The lesson is still something that needs to be learned: that movements and causes will only prevail through solidarity with the oppressed and colonized. The Spanish Republic for all its revolutionary potential and liberatory social change, was still tied in colonialism and racism. While the Anarchists of the CNT-FAI and most of the Socialists of Catalonia supported the prospects of decolonization, the system set up across the Republic was still built on the colonial system. The fall of the Republic and its failure in the Civil War are hinged on a multitude of reasons and histories. Yet amongst all the discourse of military tactics, politics, and social change, there is very little talk about the fact that even as a Republic, Spain was still a colonial empire. Even less is mentioned about that fact that after most of the government was made up of Radical Socialists, it was still a colonial empire. The lesson is that even though so many sought a radical break from the past, they still could not break with the benefits of superiority and Eurocentrism that was so antithetical to their beliefs. Thus, the real importance of Morocco in the war was not its weapons, but the fact that it questions what could have happened had the Republic truly been for freedom, had it decolonized and broken with the Colonial powers. Perhaps a revolt in Morocco would have completely disrupted the Fascists enough to allow for a Republican victory. It may have created an independent or autonomous Morocco that could have sparked further decolonization in the French Colonies. However, none of these potentialities happened because Spain "paid the price for the empire". This is a lesson that teaches to this day that it is always vital for a movement to be intersectional and decolonial if it is to truly liberate all people.

${ }^{57}$ Padmore, "Why Moors help Franco." 


\section{Bibliography}

Allard, Elisabeth. "The Crescent and the Dagger: Representations of the Moorish Other during the Spanish Civil War." Bulletin of Spanish Studies 93, no. 6 (October 2015): 965-988. https://doi.org/10.1080/14753820.2015.1082811.

Bennis, Samir. "Franco's Recruitment of Moroccans in Spanish Civil War: The Forgotten Injustice (Part I).” Morocco World News, July 9, 2012. https://www.Moroccoworldnews.c om /2012 /07 /47357 /francos-recruitment-ofmoroccans-in-spanish-civil-war-the-forgott en-injustice-part-i-2/.

Bennis, Samir. "Participation of Moroccans in the Spanish Civil War (Part II)." Morocco World News, last modified February 4, 2013. https://www.moroccoworldnews.c om/20 13/02/76826/participation-of-moroccans-in-the-spanish-civil-war-part-ii/.

Bennis, Samir. "Participation of Moroccans in the Spanish Civil War (Part III)." Morocco World News, March 3, 2013. https://www.moroccoworldnews.com/2013/03/80909/participation -of-moroccans-in-the-spanish-civil-war-part-iii-2/.

Ceasire, Aime. Discourses on Colonialism. New York: Monthly Review, 2001.

Chomsky, Noam. On Anarchism. New York: The New Press, 2013.

Jackson-Schebetta, Lisa. Traveler, There is no Road, Theater, the Spanish Civil War, and the Decolonial Imagination in the Americas. Iowa: University of Iowa Press, 2017.

Jerde, Minda. “'Brother' North: Morocco's Involvement in the Spanish Civil War.” The Volunteer, January 4, 2013. https://albavolunteer.org/2013/01/\%e 2\%80\%9cbrother $\%$ e2\%80\%9d-north-morocco\%e2\%80\%99s-involvement-in-the-spanish-civil-war/.

Landis, Arthur. Spain, The Unfinished Revolution. New York: International Publishers, 1975.

Moshiri, Nazanine. "Arabs on both sides of the Spanish civil war." The New Arab, September 1, 2016. https://english.alaraby.co.uk/english/indepth/2016/9/1/arabs-on-both-sides-of-the-s panish-civil-war.

Orwell, George. Homage to Catalonia. Scotts Valley: CreateSpace, 2014.

Padmore, George. “Why Moors help Franco.” New Leader, May 20, 1938.

Ramet, Sabrina. Alternatives to Democracy in Twentieth Century Europe: Collectivist Visions of Alternative Modernity. Baltimore: Central European University Press, 2019.

Romero, Miguel. "David Rousset's Testimony." The Spanish Civil War in Euzkadi and Catalonia, Contrasts and Convergences, Notebooks for Research and Study, No. 13. (1991): 41-43. 
Thomas, Hugh. The Spanish Civil War. New York: Random House, 2001.

Trotsky, Leon. The Spanish Revolution (1931-1939). New York: Pathfinders Press, 1973. 